\begin{tabular}{c} 
Volume and Issues Obtainable at Center for Sustainability Research and Consultancy \\
Journal of Business and Social Review in Emerging Economies \\
ISSN: 2519-089X \& ISSN (E): 2519-0326 \\
Volume 7: Issue 4 December 2021 \\
JSRᄃ \\
Journal homepage: www.publishing.globalcsrc.org/jbsee \\
\hline
\end{tabular}

\title{
Social Ties impacting Audit Quality Exploring Government Entities
}

*Madiha Irshad, The Islamia University of Bahawalpur, Pakistan

Amna Noor, The Islamia University of Bahawalpur, Pakistan

*Corresponding author's email: madihairshad@ymail.com

\begin{tabular}{l}
\hline ARTICLE DETAILS \\
\hline History \\
Revised format: Nov 2021 \\
Available Online: Dec 2021 \\
\hline Keywords \\
$\begin{array}{l}\text { Social Ties, Corruption, } \\
\text { Government Sector, Audit } \\
\text { Quality }\end{array}$
\end{tabular}

JEL Classification

M42, E42

\section{ABSTRACT}

Purpose: The purpose of the study is to analyze the first hand data regarding intimacies between government entities and government audit institution of Pakistan, to see its impact on the quality.

\section{Design/Methodology/Approach:}

Qualitative research design is used to explore the concept base on theoretical saturation technique.

Findings: The results revealed by default presence of social ties among interactive agents. It further explores indirect relationship between audit quality and social interactions in the presence of petty corruption due to familiarity, unwarranted mutual trust and favoritism however this relationship is shifted toward direct relationship in the presence of material corruption due to fear of losing good reputation, loss of job, fear of departmental inquiry, threat of floating your weaknesses before your rival clique.

Implications/Originality/Value: The results presented in this paper should therefore be of great interest to government, regulators and standard-setters charged with developing accounting standards to improve the audit quality of reporting information related to existing government auditing setup.

(C) 2021 The authors, under a Creative Commons AttributionNonCommercial 4.0

Recommended citation: Irshad, M. and Noor, A. (2021). Social Ties impacting Audit Quality? Exploring Government Entities. Journal of Business and Social Review in Emerging Economies, 7 (4), 899-907.

\section{Introduction}

William Little (2016) infamously quoted social tie as a "face-to-face social encounters in which people are physically present with one another for a specified duration". Individuals and business firms prefer dealing with partners they know or have any previous connection, because knowledge, trust, and normative commitments grow over time (Granovetter, 1985). Furthermore, interactive agents are in a comfort zone and in a better position to communicate and exchange subtle and sensitive information (Granovetter, 2005). Top executives' positions of the clients and engagement auditors both have the power and discretion to influence/affect audit quality, so the social interlocking between them suggested a significant influence upon the audit quality (Qi et al., 2017).

External auditors and clients are associated with each other through different links. These links may be based on long term tenure of audit-client firm. A number of studies had been conducted previously 
where audit firm tenure impact on audit quality (Kyriakou and Dimitras, 2018; Guindy and Basuony, 2018; Jenkins and Vermeer, 2013; Al-Thuneibat, Al-Issa, and Ata-Baker, 2011; Kim and Yi, 2009; Geiger and Raghunandan, 2002; Johnson, Khurana, and Reynolds, 2002; Carcello and Nagy, 2004; Deis and Giroux, 1992) but none of these answer the question that whether long term tenure breeds social ties between parties? By focusing this question, auditor conduct audit of the client for a long period of time, it may create more chances to develop social association among them based on frequent social interactions as (William Little, 2016). This study is further important due to lack of research done on social ties of audit-client association within government setup, this work will motivate to build a new literature and uncover the new dimensions for further research.

The main purpose of the current study is to explore the presence of the social ties between employees of government institutions and external audit officers of government audit setup due to long term tenure. Secondly, the current study wants to conduct in-depth examination of social ties of (external audit officers_employees of government institutions) and its impact on the quality of the existing auditing structure of the government of Pakistan.

\section{The Literature Review \\ Social Ties and Duration of Tenure}

The term of Audit-firm tenure is used in substitution of a length and duration of an auditor-client relationship (Ball et al., 2015; Ruiz-Barbadillo, Gomez-Aguilar, Fuentes-Barbera, and Garcia-Benauet al., 2004). Lengthy auditor-client tenure period has the potential to develop closeness among auditor and the concerned client, this relationship promoting impairing audit quality and demoting auditor's independency (Al-Thuneibat et al., 2011). Frequent social encounters due to long term association between audit firm and client breed social association among them in which both parties are physically present with each other for a specific period of time (William Little, 2016). By complying the views of William Little (2016), Ball et al., (2015); Al-Thuneibat et al., (2011) and Ruiz-Barbadillo et al., (2004) it may further derive that long term tenure of auditor with auditee breeds social association among them.

\section{Social ties and Audit Quality}

The interactional effect between audit and client is very important element to influence audit quality. According to Garcia-Blandon and Argiles-Bosch (2017), the audit firm tenure and audit partner tenure do not play a relevant role in influencing audit quality without consideration of interaction effects among connecting agents. He further depicted that the interaction of both audit-partner tenure and audit-firm tenure with client shows stronger effects on audit quality than both forms of tenure separately considered.

Advocates of social interactions in term of long term tenure argues that social interaction among parties improve audit quality (Ball et al., 2015; Carcello and Nagy, 2004; Johnson et al., 2002). The presence of interpersonal association between clients and external auditor leads to improve mutual trust (Johansen and Pettersson, 2013; Granovetter, 2005) that can be used in transferring fair information (Sias and Cahill, 1998 and Gibbons, 2004), promoting transparency (Clinch et al., 2010), reduced audit effort (Guan et al., 2016) and reduced errors in audit judgment (Qi et al., 2017, He al al., 2017, Guan et al., 2016). The mutual trust and presence of affiliation further promotes information symmetry that promotes fair flow of information between the two parties. Auditors utilize the material and useful information provided by connected client while giving his final opinion that will reduce errors in his judgment, audit risk level and audit efforts (Guan et al., 2016) and further promoting better quality audit.

Opponents of social association in term of long term tenure argued that impairment in audit quality due to frequent social encounters among parties (Deis and Giroux, 1992; Geiger and Raghunandan, 2002; Tackett et al., 2004; Guan-jun \& Lin, 2009; Al-Thuneibat et al., 2011; Ball et al., 2015). The intimacy between individual clients' top positions \& external-auditors may lead to auditors' unwarranted trust in information provided by individual clients' top positions (Qi et al., 2017, He al al., 2017), undue 
influence caused by personal relationship (Tackett et al., 2004), injecting unintentional bias into auditors' judgment and decision making (Kinney et al., 2004; Francis and Michas, 2013). Hence reduce audit quality.

After in-depth investigation of prior researches it is concluded that statutory audit of the corporate sector of Pakistan conducted by the audit partner who is qualified chartered accountant and the presence of social ties in term of long term relation among auditor-client have an impact on audit quality and there is paucity of such researches in a government institution. There exists an opportunity to explore and take in-depth review of the government auditing structure where the audit is conducted by the audit officers of basic pay scale seventeen appointed against the office of Audit General of Pakistan under article 170 of the Constitution of Pakistan (1973).

\section{Methodology}

Expert's opinion is required to obtain the rich data to gain insight into concept. Interview typology is used to extract the relevant material from the interviewee. Core population is divided into two sections. One section is the experts of government entities who have direct dealing with external audit officers. These experts comprise of members of Board, Head of the Departments, Direct Finance, Budget officers, Accountants and Internal Audit officers. Other section is the experts belong to Audit General of Pakistan, the constitutional institution that comprises of auditors, audit team members and audit officers. The experts from the Audit General of Pakistan are reluctant to provide open information due to confidentiality and sensitive nature of their profession. Therefore, in order to reach the effective information, majority of the interviews are conducted from the experts belongs to first section where the interviewee relatively less hesitant and more effective to provide sensitive information based on their experiences.

The sample size of the current study is twenty interviews based on theoretical saturation. The theoretical saturation is the concept where sampling, data collection and data analysis is combined in a linear process rather than treat them separately. In theoretical saturation, the researcher continues in conducting interviews until saturation is attained and no new theoretical-insights are being gathered from the sample data (Sarah Elsie Baker and Rosalind Edwards 2012). Guests et al., (2006) achieved their saturation after interviewing twelve peoples whereas the concept of current study gets their relevant theoretical saturation at the level of twentieth interviews.

Sensitivity of research areas makes some of the interviewee to be reluctant in giving audio-recording while some of them allow recording the face to face conversation. Audio recording of interview is transcript into written documents. Afterwards the required data analysis techniques applied on written transcript to obtain and tune the data into some meaningful information. The length of each interview is approximately 40 to 90 minutes. In most of the cases, double interview sessions are conducted from single experts in order to extract the true information from available opinion. The first interview is necessary to attain familiarly and comfort with the interviewee and second interview is actually about collecting data regarding social interactions between auditee and auditor and its effect on audit quality.

Current study is not utilized the standardized set of questions; it is more open discussions about extracting the concept of social interactions between external audit officer and government institution of Pakistan. Semi-structure interviews were conducted by asking the general open ended questions. A list of themes and questions has been prepared before collecting data which vary from interview to interview. Furthermore, likewise theoretical saturation former interviews are very helpful in guiding the latterly conducting interviews in term of asking the other relevant questions for the purpose of exploring the most accurate detail within limited period of discussion. 


\section{Data Analysis}

\section{Presence of Social Ties within Government Auditing Setup}

The following interview evidences suggested that prolonged duration of the tenure of the audit officer and government association also contributes to develop an association between interacting agents within government setup based on frequent social interactions and psychological association.

"Audit by familiar team members has a more tendency to develop relations and exchange some mutually agreed benefits..."

In the same vein another interviewee stated that

"With old audit-team there is only a psychological association because of familiarity. It creates relax environment and most of the things can easily settled during discussions."

Within the government structure of auditing the annual financial audit is conducted by the employees of the offices of the Audit General of Pakistan under article 170 of the Constitution of Pakistan (1973). The working of the offices is divided in term of divisions or regions. One of the respondent stated that each division may consist of approximately 10 to 12 audit officers. However, each formation/client is to be audited by the one of the same team of audit officers within the region. As we know the life of the government entities is long run and a continuously in process. Furthermore, the relationship between government entities and government audit officer is formed under article 170 of the Constitution of Pakistan (1973) that breeds by default audit firm-client associations. Interviewee stated follows in response to the question that how many interactions are necessary to make a comfortable relationship with an audit officer?

"In practice there are about 10 to 12 audit officer within single audit general office. I have work experience since from 1985. I have one, two, three or more interactions with almost each person of audit department"

Similarly, the other opinion in the same context is

"We have strength of 8 audit officers and 8 assistant audit officers in our office to conduct audit of the whole division"

It is concluded that the social ties, in term of long term tenure between audit officers and government entities, exists within government auditing structure. Moreover, unlike to the prior literature related to corporate sector, the government entities have no choice except of Audit General Office to conduct their annual financial audit. Due to availability of limited workforce within regional/divisional audit office and continuously long term life of the government entities, creates by default social ties among interactive agents.

\section{Social Ties Impairing Audit Quality}

The social relation of the client with the auditee may contribute to reduce audit quality. The relevant evidences are given below;

It is elevated that under the influence of social ties, one can easily convince other to ignore many issues that mean reducing audit quality.

"Audit by familiar team members has a more tendency to develop relations and exchange some mutually agreed benefits" 
In the same context, the other experts stated that

External Auditors' duty is just to conduct his job; it does not matter whether audit team is new or old. With old one there is only a psychological association because of familiarity. It creates relax environment and most of the things can easily settled during discussions. But it is more preferable that the audit firm must change after two or three years because long tenure of same auditor-auditee associations create more chances of enhancing negativity"

Putnam (2000) stated in his book named "Bowling alone" about social ties and argued that development of strong social ties may result in some antisocial outcomes such as corruption, ethnocentrism etc. In the same context, the following expert observed that social ties in term of long term tenure may increase the room for corruption. He further perceived almost half of the budget is waste due to overall corruption that is a big loss to government and auditing structure.

"If same external audit-team visits the same station again and again, it will enhance the auditorauditee associations that increase the room for corruption....

"Corruption exists everywhere; private sector hidden profits and government departments are actually suffering losses as I perceived about 50\% of the total budget is waste under umbrella/cover of corruption"

It is relatively easy to motivate audit officers towards getting leniency in making audit observation under presence of social tie in term of long term duration of the service. In addition to this, he further added that high level of corruptions cannot be ignored by the audit officers in their final reporting. As, interview evidences further explore, that the due to long term audit-auditor tenure, the auditee have an idea about the behavior, experience and working capacity of the auditor. Hence it is easy to mold audit officers towards obtaining leniency. But there is an exception to this statement within government auditing structure; material-corruption has no exemption for exclusion in audit reports but leniency may be gained in the issues of petty irregularities.

"Long term audit relation is familiar face, knowhow about his language, idea about his working capacity; we know his levels of evaluations and well known about how to motivate them? It is relatively easy to motivate them toward leniency.......

The routine matter or normal things may be ignored under influence of Social ties. But not ignore the fraud even if audit observations belong to your brother, friend and any other relative...it may possible to give relaxation in the writing of the audit observation but not possible to absolutely skip the inclusion of fraud from the annual audit inspection report"

In the same context, the second interview evidence suggested that

"Behaviors of audit officers toward audit observation are relatively lenient after taking some bribe. They pointed out the audit observations having nature of smaller irregularities that is easily settled in meetings instead of reducing the numbers of audit paras.... on the other side, any type of corruption has no exemption for exclusion in audit reports but leniency may be gained in the issues of petty irregularities"

According to some expert opinions, positive social ties do not impair audit quality in presence of material corruption due to fear of losing good reputation and loss of job, fear of inquiry and threat of your clique seeking your weaknesses. Here professional benefit from doing good (disclosure of fraud) is greater than personal benefit taken from doing wrong (taking bribe and concealing facts). We can say involvement of material corruption will make the audit of concerned vouchers/documentations/ transaction purely unbiased and improve the partial audit quality. 
"The audit officers do not compromise his independency in presence of corruption because of gaining good reputations from their high ups. That's why giving bribe to audit officers don't mean he do not point out material corruption. He will definitely have pointed out corruption and also made other numbers of observations otherwise their higher authorities questioning/doubting about his independence and may stand enquiries upon him...members of the enquiry committee are the cliques of the concerned audit officer who indulges in seeking weakness of one another"

In the same vein, another respondent is of the following views

" Audit officer cannot ignore any fraud noted by him, he has a threat to lose his job"

\section{Social Ties Improving Audit Quality}

The following Interviewee briefly relates social interactions in term of long term tenure and better audit quality and agrees with (Guan et al., 2016) the use of social ties in obtaining fair flow of information that is helpful in attaining accuracy in final audit opinion.

"The experienced audit officer knows more about the areas of his consideration...He develop links and croods with the departmental staff and ask about the internal issues and problems. They use the internal information to get dominancy over others"

Audit quality will be improved because the intimacy due to long term tenure made the audit officer, to have in-depth information about the weak areas of the formation and induce the pressure on formation to overcome and improve the deficiencies.

"It is more comfortable to have the same external team to audit the institution because we are familiar from their way of work, mentality and level of capability. We can forecast best that which type of areas he concentrated more. So accordingly, we prefer effective working of these highlighted areas prior to external audit. "

Current study concluded that positive social ties may be directly relates to improving audit quality because of the familiar and long term tenure made the audit officer to have in-depth information about the weak areas of the formation and induce the pressure on formation to overcome and improve the weak areas. Furthermore, fair flow of information and unintentional mutual trust of connecting parties contributed improving audit quality.

\section{Research Conclusion and Recommendations}

Current study observes the presence of social ties between audit officers and government entities exists within government auditing structure. Moreover, in contrary to the corporate sector, the non-corporate government entities have no choice except of Audit General Office to conduct their annual financial audit. Due to availability of a one audit office with limited workforce in each regional/divisional and continuously long term life of the government entities, creates by default presence of social ties among interactive agents.

It further explores the presence of social ties among employees of government entities and audit officers of government setup of Pakistan. There exists indirect relationship between audit quality and social interactions in the presence of petty corruption due to familiarity, undue influence, unwarranted mutual trust and favoritism but this relationship is shifted toward direct relationship between audit quality and social ties in the presence of material corruption due to fear of losing good reputation, loss of job, fear of departmental inquiry, threat of floating your weaknesses before your rival clique. 
The study further infers the results in term of material corruption and petty corruption. The presence of positive social ties may promote some sort of minor corruption regarding to petty irregularities within government setup of auditing on the part of the audit officer as well as of the auditee but the materialcorruption has no exemption for exclusion in audit reports. However, it concludes that the auditing structure of the government setup not absolutely weak because of definite inclusion of the material corruption within annual inspection reports. In the observance of material corruption, the audit quality will be improved even there are strong social ties among connected parties due to fear of losing good reputation, loss of job, fear of inquiry, threat of your clique seeking your weaknesses and have an upper hand. At this point, professional benefit from good doing (disclosure of material corruption) is greater than personal benefit taken from wrong doing (taking bribe and concealing facts/minor corruption). As a cost benefit analysis, the involvement of material corruption will make the audit of concerned vouchers/documentations/ transaction purely unbiased and improve the audit quality partially. Hence, it may be concluded that the audit quality of government entities is about moderate level. The social ties contribute to impair audit quality but it is inclined toward better audit quality in case of material inconsistency arises among reporting and procedures.

It is not possible to exclude social ties government institutions \& government auditing setup of Pakistan. It is more favorable that government should design more strategical transfer and promotional polices to reduce the adverse impact of social ties on audit quality. The results presented in this paper should therefore be of interest to government, regulators and standard-setters charged with developing accounting standards to improve the audit quality of reporting information with existing government auditing setup. Future research could further explore by examining the current issue from perspective of private sector that involve participation of external auditor in determining the audit quality due to effects of social ties. Current study could be conducted from quantitative point of view.

\section{References}

A.A.Al-Thuneibat, R.T.B.AL Issa and R.A.Ata-Baker. 2011. "Do audit tenure and firm size contribute to audit quality?" Managerial Auditing Journal 26(4): 317-334.

Alex Appelman. 2017. The effect of social ties on audit fees. theses.ubn.ru.nl/bitstream/handle/.../MTHEC_RU_Alex_Appelman_s4669517.pdf?

Alexander Isakov,James H. Fowler, Edoardo M. Airoldi and Nicholas A. Christakis. 2019. "The Structure of Negative Social Ties in Rural viilliage networks." Sociological Sciences 6: 197-218.

Al-Sukker, A., Ross, D., Abdel-Qader, W., \& Al-Akra, M. . 2018. "External auditor reliance on the work of the internal audit function in Jordanian listed companies." International Journal of Auditing 22(2): 317-328.

Al-Twaijry, Abdulrahman, John A. Brierley, and David R. David . Gwilliam. 2004. "An examination of the relationship between internal and external audit in the Saudi Arabian corporate sector." Managerial Auditing Journal (Emerald Group Publishing Limited) 19 No. 7: 929-944.

Baolei Qi, Rong Yang \& Gaoliang Tian. 2017. "Do social ties between individual auditors and client CEOs/CFOs matter to audit quality?" Asia-Pacific Journal of Accounting \& Economics 24:3-4: 440-463.

Borgatti, S. P., A. Mehra, D. J. Brass, and G. Labianca, G. 2009. "Network analysis in the social sciences." Science 323 (5916): 892-895.

Brands, R. A., and M. Kilduff. 2013. "Just like a woman? Effects of gender-biased perceptions of friendship network brokerage on attributions and performance." Organization Science 25(5): 1530-1548.

Carcello, Joseph V, and Albert L Nagy. 2004. "Audit firm tenure and fraudulent financial reporting." $A$ Journal of Practice and Theory 23 (2): 55-69.

Carolina, Yenni. 2013. "An Empirical Study of Auditor Independence, Competence and Audit Tenure on Audit Quality - Evidence from North Jakarta, Indonesia." International Conference on Business and Mangement.

Chad M. Stefaniak and Robert M. Cornell. 2011. "Social Identification and Differences in External and 
Internal Auditor Objectivity." Current Issues in Auditing 5 (2): 9-14.

Clinch, G., Stokes, D.J. and Zhu, T. 2010. "Audit Quality and Information Asymmetry Between Traders." Accounting \& Finance 52 (3): 743-765.

D. Jenkins and Thomas E. Vermeer. 2013. "Audit firm rotation and audit quality: evidence from acedemic research." Accounting Research Journal 26 (1): 75-84.

Daniela Argento, Timurs Umans, Patricia Hakansson and Annika Johansson. 2018. "Reliance on the internal auditors' work: experiences of Swedish external auditors." Journal of Management Control 29: 295-325.

Donald R. Deis and Gary A. Giroux. 1992. "Determinants of audit quality in the public sector." The Accounting Review 67 (3): 462-479.

Emiliano Ruiz-Barbadillo, Nieves Gomez-Aguilar, Cristina De Fuentes-Barbera and Maria Antonia Garcia-Benau. 2004. "Audit Quality and the Going-concern Decision-making Process: Spanish Evidence." European Accounting Review 14 (4): 597-620.

Felix, W.L. Jr, Gramling, A.A. and Maletta, M.J. 2001. "The contribution of internal audit as a determinant of external audit fees and factors influencing this contribution." journal of Accounting Research 39 (3): 513-534.

Fiona Ball, Jonathan Tyler, Peter Wells. 2015. "Is audit quality impacted by auditor relationships?" Journal of Contemporary Accounting \& Economics 11 (2): 166-181.

Francis, J., and P. N. Michas. 2013. "The Contagion Effect of Low-Quality Audits." The Accounting Review 88(2): 521-552.

Gant Larry M, Ostrow David G. 1995. "Perceptions of Social Support and Psychological Adaptation to Sexually Acquired HIV among White and African American Men." Social Work 40 (2): 215-24.

Gibbons, D.E. 2004. "Friendship and advice networks in the context of changing professional values." Administrative Science Quarterly 42(2): 238-262.

Granovetter, M. 2005. "The impact of social structure on economic outcomes." Journal of Economic Perspectives 19(1): 33-50.

Guan-jun, ZHANG, and ZHANG Lin. 2009. "An analysis on dealing with audit failure." Journal of Modern Accounting and Auditing (ISSN) 5 (7).

Jeong-B Kim and cheong H. Yi. 2009. "Does auditor designation by the regulatory authority improve audit quality: evidence from Korea." Journal of Accounting and Public policy 28 (3): 207-230.

Johansen, T. R., \& Pettersson, K. 2013. "The impact of board interlocks on auditor choice and audit fees." Corporate Governance (Oxford) 21(3): 287-310.

Johnson, V., Khurana, I. and Reynolds. 2002. "Audit-firm tenure and the quality of financial reports." Contemporary Accounting Research 19 (4): 637-660.

Josep Garcia-Blandon and Josep Maria Argiles-Bosch. 2017. "The interaction effects of firm and partner tenure on audit quality." Accounting and Business Research 47 (7): 1-21.

Kinney, W. R., Z. V. Palmrose, and S. Scholz. 2004. "Auditor Independence, Non-Audit Services, and Restatements: Was the U.S. Government Right?the U.S. Government Right?" Journal of Accounting Research 42(3): 561-588.

Lincoln, Karen D. 2000. "Social Support, Negative Social Interactions, and Psychological Well-Being." Social Service Review 74 (2): 231-252.

Little, William. 2016. Introduction to Sociology; 2nd Canadian edition. Available at: https://opentextbc.ca/introductiontos.

M.I. Kyriakou and A.I. Dimitras. 2018. "Impact of auditor tenure on audit quality: European Evidence." Investment Management andFinancial Innovations 15 (1): 374-386.

Mai Stafford, Paola Zaninotto and James Nazroo. 2011. "Positive and Negative Exchanges in Social Relationships as Predictors of Depression: Evidence From the English Longitudinal Study of Aging." Journal of Aging and Health 23 (4): 607-628.

Mark A. Rademacher and Kevin Y. Wang. 2014. "Strong-Tie Social Connections Versus Weak-Tie Social Connections Scholarship and Professional Work - Communication." http://digitalcommons.butler.edu/ccom_papers/103.

Marshall A. Geiger and K. Raghunandan. 2002. "Auditor tenure and audit reporting failures." A Journal 
of Practice \& Theory 21 (1): 67-78.

Medhat N. El Guindy \& Mohamed A. K. Basuony. 2018. "Audit Firm Tenure And Earnings Management: The Impact Of Changing Accounting Standards In UK Firms." Journal of Developing Areas, Tennessee State University, College of Business 52(4): 167-181.

Putnam, Robert D. 2000. "Bowling Alone." New York: The Collapse and Revival of American Community. doi:DOI:10.1145/358916.361990.

Qawqzeh, H. K., Endut, W. A., Rashid, N., Johari, R. J., Hamid, N. A., \& Rasit, Z. A. 2018. "Auditor Tenure, Audit Firm Rotation and Audit Quality: A Literature Review." International Journal of Academic Research in Business and Social Sciences 8(12): 1314-1324.

Rose, J.M. 2007. "Attention to evidence of aggressive financial reporting and intentional misstatement judgments: Effects of experience and trust." Behavioral Research in Accounting 19 (1): 215-229.

Sarah Elsie Baker and Rosalind Edwards. 2012. "How many qualitative interviews is enough?" http://eprints.ncrm.ac.uk/2273/4/how_many_interviews.pdf.

Sias, P.M., and D.J. Cahill. 1998. "From coworkers to friends: The development of peer friendships in the workplace." Western Journal of Communication 62(3): 273-299.

Uzzi, B. 1996. "The sources and consequences of embeddedness for the economic performance of organizations: The network effect." American Sociological Review 61 (4): 674-698.

Whittington, R. and Margheim, L. 1993. "The effects of risk, materiality, and assertion subjectivity on external auditors' reliance on internal auditors." Auditing; A journal of Practice \& Theory 12 (1): 50-64.

Xianjie He, Jeffrey A. Pittman, Oliver M. Rui, and Donghui Wu. 2017. "Do Social Ties between External Auditors and Audit Committee Members Affect Audit Quality?" The Accounting Review 92(5): 61-87.

Yuyan Guan, Lixin Nancy Su, Donghui Wu, Zhifeng Yang. 2016. "Do school ties between auditors and client executives influence audit outcomes." Journal of Accounting and Economics 61: 506-525. 